\title{
ПРОБЛЕМИ ТА МОЖЛИВОСТІ РОЗВИТКУ УРБАНІСТИЧНОГО СЕРЕДОВИЩА
}

\section{PROBLEMS AND OPPORTUNITIES FOR THE DEVELOPMENT OF THE URBAN ENVIRONMENT}

\begin{abstract}
Ільчук Н.І., к.т.н., доц., (Луцький національний технічний університет університет), Ільїна О.В., к.геогр.н. (Волинський національний університет імені Лесі Українки)

Ilchuk N.I., PhD, Associate professor, (Lutsk National Technical University), Ilyina O.V., PhD, Associate professor, (Lesya Ukrainka Volyn National University)
\end{abstract}

Проведено аналіз проблем розвитку урбанізованого середовища. Визначено перспективи вдосконалення систем управління міським середовищем. Проаналізовано загальний світовий підхід щуодо можливостей розвитку урбаністичного середовища в майбутньому.

The analysis of problems of development of the modern urban environment is carried out. Prospects for improving urban management systems are identified. The general world approach to the possibilities of development of the urban environment in the future is analyzed.

The creation of new cities and their possible development are closely linked to social, political and economic aspects. Mankind has always sought a better future.

Research and planning for the future development of cities have become necessary requirements of today. Both the cities themselves and the national governments of the world are interested in this.

For further defined and sustainable development, it is necessary to have national urban strategies and global institutions that allow to take into account the contribution of cities in solving a number of global problems, such as climate change, epidemics, terrorism.

The social aspect is also very important, ie city residents must consciously think about how to change their city for the better, what exactly citizens want to see, how it is possible to improve their living standards and environment, to be actively involved in making all important decisions for the city.

It is expedient to focus research on cities, because they are the implementation of state policy, a densely concentrated large number of people, a large number of places of employment, cultural and educational institutions.

Ключові слова: місто, урбанізоване середовище, мегаполіс.

Keywords: city, urban environment, megalopolis.

Постановка проблеми. Створення нових міст та можливий їхній розвиток досить тісно пов'язаний із соціальними, політичними, економічними аспектами. Людство завжди прагнуло кращого майбутнього. Сучасний світ охоплює урбанізація. За прогнозами експертів 
у 2050 році близько 70\% населення світу буде проживати у містах. Якими вони повинні бути і що потрібно передбачити для їхнього стабільного розвитку? Вчені багатьох країн вивчають сучасні тенденції та проблеми розвитку урбаністичного середовища, а також вплив новітніх технологій на міське життя в цілому [1].

Аналіз відомих досліджень і публікацій. Проведення наукового дослідження та планування майбутнього розвитку міст стали необхідними вимогами сьогодення. В цьому зацікавлені як самі міста, так і національні уряди країн світу. Для подальшого визначеного та стабільного розвитку необхідно мати національні урбаністичні стратегії та глобальні інституції, які дозволяють враховувати внесок міст у вирішення ряду глобальних проблем, таких як зміна клімату, епідемії, тероризм.

Якщо проаналізувати розвиток міського середовища кінця XX століття, то можна побачити величезні «вертикальні» міста, де як засіб основний засіб пересування використовуються різні види транспорту. Але 3 часом на перший план вийшла екологія. Саме тому, індивідуальне уявлення та розуміння розвитку міста, як правило і формують вектор його розвитку в майбутньому $[1,2]$.

Кількість людей, які чітко усвідомлюють свій можливий вплив на навколишнє середовище, істотно збільшується.

Мета статті: проаналізувати можливості та проблеми розвитку урбанізованого середовища, які виникають на теренах світового розвитку мегаполісів.

Відповідно до поставленої мети вирішуються наступні завдання:

- проаналізувати можливості розвитку урбаністичного середовища;

- проаналізувати способи та методи управління системами міського середовища та визначити їхній вплив на формування мегаполісів.

Аналіз можливостей розвитку урбаністичного середовища. На даний час спостерігається тенденція до розбудови smart city - «розумне місто», для якого характерним є використання різних технологій для досягнення максимальної взаємодії і зв'язку між різними частинами міста, навіть взаємодія між мобільними та домашніми приладами, коли можна прийти додому, а смачна вечеря вже готова. В той самий час, великі та перевантажені мегаполіси не завжди можуть бути комфортними для життя. Саме тому, міста майбутнього повинні бути не лише високотехнологічними, але і зручними для їх мешканців. Вони повинні мати середню щільність населення, мати місця для прогулянок та відпочинку, розвинену мережу пішохідних та велосипедних доріжок, зони озеленення та рекреації для покращення загального мікроклімату міського середовища.

Прогнозовано, що зміни торкнуться не лише зовнішнього вигляду міста, а також і можливостей впливу звичайної людини на його життя та планування. Smart city («розумні міста») - це коли мешканці міста за 
допомогою новітніх технологій та інтернету можуть впливати на рішення щодо модернізації міста.

Візуалізація даних щодо розвитку міського середовища з можливістю керувати усіма процесами, спочатку з'явилася в комп'ютерних іграх. На сьогодні вже існують спеціальні «дашборди» - панелі управління, які дають можливість в реальному часі побачити різні процеси: рух транспорту, кількість населення, смертність та інші дані, які характеризують життя міст в цілому. Такі системи управління стають невід'ємною частиною розвитку урбанізованого середовища. За допомогою таких «дашбордів» стає можливим аналізувати та пізнавати місто, а також відстежувати ефективність усіх процесів, які відбуваються в ньому.

Крім того, дуже важливим є і соціальний аспект, тобто мешканці міста повинні свідомо думати, як саме змінити на краще своє місто, що саме хочуть бачити містяни, як саме можна покращити стандарти свого життя та довкілля, бути активно задіяними у прийнятті всіх важливих для міста рішень. Сучасне місто - це не лише справа міського самоврядування, уряду або політики, це майбутнє, яке стосується всіх і кожного, адже жити комфортно, можна лише свідомо узгоджуючи різні сфери життєдіяльності [1].

Доцільним є зосередження досліджень саме на містах, адже в них проходить реалізація політики держави, щільно сконцентрована велика кількість населення, зосереджена велика кількість місць прикладання праці, культурних та освітніх закладів; саме вони є не лише виробниками, але і споживачами наукових ідей, матеріальних благ і культури.

Аналітичні дані говорять про те, що міста являють собою змінну систему, вони як живі організми, які мають свою історію розвитку та займають певний простір і в той же час $є$ неоднорідними. Як наслідок, усі міські системи є непередбачуваними та нестабільними, тому їх не можна повністю контролювати та прогнозувати [1,2].

Звичайно, усі прогностичні обчислювання можуть бути корисними для вирішення багатьох завдань, наприклад, покращення умов руху на вулицях та дорогах міст і запобігання виникнення заторів, проектування інженерних мереж міста та інших процесів, але вони не підходять для розрахунку майбутньої поведінки мешканців.

Саме тому виникає необхідність візуалізувати саме цей масив інформації про місто у зручній формі, щоб дедалі більше мешканців могли використовувати інформацію для власних потреб.

Для покращення процесу прийняття рішень, наприклад, щодо вдосконалення міського ландшафту, необхідно щоб була можливість та доступність для всього суспільства, а не лише для міського самоврядування та інших зацікавлених сторін. Необхідно створювати зрозумілі та доступні інтерфейси, за допомогою яких архітектори та міські 
дизайнери зможуть вільно ділитися інформацією з громадськістю, а також залучати ії для обговорення та прийняття рішень.

Застосування різних методів обчислення не допоможе вирішити всі існуючі проблеми, але дасть новий погляд на місто, відкриє його приховані характеристики, допоможе пояснити існуючу ситуацію. Наприклад, аналіз даних GPS із мобільних телефонів користувачів автобусного транспорту дає можливість ідентифікувати нові маршрути, а також виконати необхідні зміни в уже існуючих, що в подальшому призводить до підвищення пасажиропотоку в цілому $[1,2]$.

Аналіз способів та методів управління системами міського середовища та визначення їхнього впливу на формування мегаполісів. Існуюча міська політика та дизайн архітектурного середовища повинні бути максимально чіткими та прозорими, із використанням інтерактивних інструментів для міського розвитку. Саме тоді архітектура та планування можуть стати соціально перетворювальною силою. За допомогою активної участі громади можна отримати швидкі зміни та ефективно використовувати ресурси міста [2,3].

В реаліях сьогодення, традиційні методи проектування, містобудування та ландшафтного дизайну поступаються новим - це побудова певного середовища із залученням та за участі мешканців міста. Що в свою чергу дає можливість поєднати дві системи управління: зверхувниз i знизу-вгору. Тому головним завданням $\epsilon$ створити загальний інформаційний ресурс для розвитку міст, який буде доступний для різних категорій його мешканців.

Прогнозовано, що урбанізація буде нерівномірною. В країнах Африки у період з 2020-2050 рр. вона зростатиме найбільше, а деякі країни, такі як Японія та Росія, навпаки, за кількісними показниками будуть втрачати мешканців міст. Більше третини нових урбаністичних зон, близько $37 \%$, за прогнозами, можуть з'явитися в Індії, Китаї та Нігерії [1,2].

Як зазначалося, близько $70 \%$ людей планети мешкатимуть в урбаністичних районах. Власне міста будуть різного розміру, в тому числі велика кількість мегаполісів: близько 40 до 2050 року, проти 28 на сьогодні, але більшість населення буде жити у містах з населенням менше 500 тис. осіб.

Основними типами міст у майбутньому $є$ мегаполіси, переважна більшість з яких зосереджені на Сході, здебільшого це країни Африки, Центральної та Латинської Америки та більшої частини Азії; найзначніші та значні міста з чисельністю мешканців близько 1-10 млн. чол. - шість таких міст будуть в Китаї вже до 2025p, також кілька в Африці; великі міста - це близько 500 тис - 1 млн.чол., зосереджені в основному в Азії та Африці; середні та малі міста, які мають населення до 500 тис.чол, переважають у Свропі - в них житиме близько двох третин мешканців 
країн $\mathrm{CC}$, а в цілому - це половина урбаністичного населення, яке буде вже до 2030 року [1,2].

Враховуючи світовий досвід становлення та розвитку різних категорій міст, варто врахувати можливості, які виникають при поєднанні різних тенденцій та пріоритетів їхнього розвитку.

На сьогодні у світі спостерігається загальна тенденція до збільшення кількості населення, тому важливим є питання: які саме регіони люди обиратимуть для свого проживання у майбутньому.

Нові технології дозволяють змінювати географію виробництва. У зв'язку з розповсюдженням та можливостями 3-D моделювання, воно вже не $\epsilon$ прив'язаним лише до конкретного місця чи певного заводу. Саме завдяки розвитку інженерно - комп'ютерної техніки $є$ можливість працювати вдома, також розвиваються, так звані, «треті місця» для проведення зустрічей, комунікації і роботи, що призводить до зміни транспортного навантаження у містах.

Сучасні міста споживають надзвичайно велику кількість матеріалів і ресурсів. Потенційно міста пропонують більш ресурсно - ефективне життя, але тим самим, створюють головні проблеми, які полягають у порушені ланцюга постачання. Однією 3 найважливіших проблем $\epsilon$ необхідність щодо зменшення використання води та інших природних ресурсів. Прогнозовано, що до 2050 року окремі регіони зможуть знизити щорічне використання води річок та озер, якщо будуть враховувати необхідність зберігати та відновлювати природні ресурси [1, 2].

Досить гостро відбувається інтеграція та взаємозалежність інфраструктур енергетики, транспорту, побутових відходів та води. Сьогодні на перший план виходить можливість щодо покращення ефективності і якості надання послуг. Серед найбільш важливих питань $\epsilon$ скорочення величезної кількості відходів, які місто продукує щодня.

Перспективним у розвитку урбанізованого середовища $\epsilon$ впровадження нових типів транспорту для мобільності міського населення - використання невеликого за своїми розмірами, автономного, 3 незначними викидами вуглецю індивідуального транспорту, популярними залишаться велосипеди та електротранспорт різної модифікації.

Слід зауважити загальну тенденцію щодо щільності та компактності міст, особливо в центрі, тому необхідним є проведення озеленення, що матиме значний вплив на здоров'я усіх мешканців та покращить загальний архітектурно - композиційний обрис міста.

Перспективною $є$ практика впровадження різних видів міського управління. Дедалі важливішу роль у містах відіграватиме «інтернет речей» - це $\epsilon$ мережа об'єктів, які завдяки сучасним технологіям взаємодіють між собою і 3 навколишнім світом. В умовах існуючої реальності, спостерігається суспільна мобільність населення через соціальні мережі, що стало частиною нашого щоденного життя. В 
загальному процесі управління містом роль його мешканців змінюється вони отримають змогу брати безпосередню участь в обговореннях щодо міських просторів, у процесах їхнього перетворення. Загальний аналіз даних в реальному часі дає можливість ефективніше керувати усіма процесами, які відбуваються в місті. Покращення методів комунікації відбувається саме в умовах використання соціальних мереж.

Основними завданнями та викликами, які постануть перед містами в майбутньому це ріст населення, а також проблеми, які взаємопов'язані $з$ іншими аспектами урбанізованого розвитку міст. Серед основних можна виділити наступні: як і де міста можуть розмістити мешканців, кількість яких зростатиме протягом наступних 50 років; зміна життєвих стандартів міського населення; конкурентність, яка пов'язана 3 можливістю міст бути продуктивними i конкурентними в умовах нових економічних можливостей; підхід до стандартів здоров'я та чистоти середовища, а саме: як зробити міста більш екологічними та безпечними; аналіз та регулювання наявних зв'язків, а саме: чи потрібно і як саме розвивати зв'язки між містами. Отже, саме комплексне вирішення усіх цих питань дасть можливість уникнути проблем пов'язаних 3 розвитком урбаністичного середовища в майбутньому.

\section{Висновки.}

Проведено аналіз можливостей розвитку урбанізованого середовища, що підтверджує передумови функціонування різних типів та систем населених місць із врахуванням особливостей їх формування.

Проаналізовано способи та методи управління системами міського середовища та визначено їхній вплив на формування мегаполісів.

Для покращення умов функціонування урбаністичного середовища необхідним є створення загального інформаційного ресурсу, який буде доступний для різних категорій його мешканців.

\section{References}

1. Ofitsiinyi sait zhurnalu «Korydor» - Rezhym dostupu: http://www.korydor.in.ua/ua/ideas/smart-cities.

2. Ofitsiinyi sait zhurnalu «Visnyk ekonomichnoi nauky Ukrainy» - Rezhym dostupu: https://iie.org.ua/visnik-ekonomichnoyi-nauki-ukrayini/

3. DBN B.2.2 - 12:2018 «Planuvannia i zabudova terytorii»

4. DBN B.1.1-22:2017 «Sklad ta zmist planu zonuvannia terytorii»

\section{Список використаної літератури}

1. Офіційний сайт журналу «Коридор» - Режим доступу: http://www.korydor.in.ua/ua/ideas/smart-cities.html

2. Офіційний сайт журналу «Вісник економічної науки України» - Режим доступу: https://iie.org.ua/visnik-ekonomichnoyi-nauki-ukrayini/

3. ДБН Б.2.2 - 12:2018 « Планування і забудова територій»

4. ДБН Б.1.1-22:2017 «Склад та зміст плану зонування територій» 